Original Article

\title{
Blood cells and some hematological parameters of red drum (Linnaeus, 1766) in Vietnam
}

\author{
Células sanguíneas e alguns parâmetros hematológicos do tambor vermelho \\ (Linnaeus, 1766) no Vietnã \\ D. H. Quyet ${ }^{\mathrm{a}}$ (1) \\ ${ }^{a}$ Water Ecology Division - Institue of Tropical Ecology, Vietnam-Russia Tropical Center, Cau Giay District, Hanoi, Vietnam
}

\begin{abstract}
This research focuses on hematological characteristics, erythrocyte morphology and some biochemical parameters of red drum Sciaenops ocellatus (Perciformes: Sciaenidae), cultured in natural water environment in areas near river mouth (L1), estuaries (L2) in Ha Tinh province and coastal areas (L3) in Nha Trang city, Khanh Hoa province of Vietnam. A total of 18 speciments were examined in research, six in each location. Blood was drawn from the tail vein, using a microscope to research morphology and automated gauges to determine blood biochemical parameters. Analysis of blood samples showed that the rate of red drum's erythrocyte morphology disorders in all three locations was quite high. The two main types of disorders were nuclear deformity and nuclear-matter distribution. Changes in erythrocyte size, shape and nuclear were related to salt concentration at culture locations. Blood hemoglobin content was stable in all three regions. Other hematological parameters such as the number of erythrocytes, blood biochemical parameters (glucose, SGOT, SGPT, urea, creatine, plasma iron, albumin, and protein) have differences among the locations, which showed the different reactions of the same species with different environmental conditions.
\end{abstract}

Keywords: red drum, blood, fish, erythrocyte, environment.

\begin{abstract}
Resumo
Esta pesquisa se concentra nas características hematológicas, na morfologia eritrocitária e em alguns parâmetros bioquímicos do tambor vermelho Sciaenops ocellatus (Perciformes: Sciaenidae), cultivado em ambiente aquático natural em áreas próximas à foz do rio (L1), em estuários (L2) na província de Ha Tinh e em áreas costeiras (L3) na cidade de Nha Trang, província de Khanh Hoa do Vietnã. Um total de 18 espécimes foi examinado na pesquisa, seis em cada local. O sangue foi coletado da veia da cauda, usando um microscópio para pesquisar a morfologia e medidores automatizados para determinar os parâmetros bioquímicos do sangue. A análise das amostras de sangue mostrou que a taxa de distúrbios morfológicos dos eritrócitos do tambor vermelho em todos os três locais era bastante alta. Os dois principais tipos de distúrbios eram deformidade nuclear e distribuição de matéria nuclear. Mudanças no tamanho, na forma e no núcleo dos eritrócitos foram relacionadas à concentração de sal nos locais de cultivo. O conteúdo de hemoglobina no sangue era estável em todas as três regiões. Outros parâmetros hematológicos, como número de eritrócitos, parâmetros bioquímicos sanguíneos (glicose, SGOT, SGPT, ureia, creatina, ferro plasmático, albumina e proteína), apresentam diferenças entre os locais, o que evidencia diferentes reações de uma mesma espécie em diferentes ambientes e condições.
\end{abstract}

Palavras-chave: red drum, sangue, peixe, eritrócitos, meio ambiente.

\section{Introduction}

The speed of urbanization and industrialization in the shore areas has always been in direct proportion to the environment pressure. The effect of heavy metals is of special interest due to their wide range of impacts and their range of concentration that adversely affect aquatic lives. Waste from factories in industrial parks becomes the main sources of metal pollution to water in nature (Livingstone, 2001). Wastewater from urban area flows to the sea through a system of channels, rivers

and streams. Wastewater from processing plants or industrial zones which can be treated or not completely treated, or even untreated, is discharged into the sea. The water system in aquaculture exposes to a number of pollutants mainly discharged from factories, sewage treatment plants, and drainage water from urban areas and agriculture. These pollutants cause serious impacts to aquatic animals (Karbassi et al.,2006; A1Masri et al., 2002). 
A large part of these elements cause a toxic effect by producing reactive oxygen species (ROS), which cause oxidative stress. Most of heavy metals are toxic carcinogenic and pose threat to environment as well as humans (Damien et al., 2004; Farombi et al., 2007).

Heavy metals have a long biological half-life period and are therefore a major threat to aquatic organisms, especially fish. Heavy metals at high concentration are lethal to aquatic lives; at sublethal concentrations, they accumulate in the organism and more and more along the food chain. The danger of heavy metals to human health becomes evident only when humans use aquatic organisms, including fish, as their daily food (Ranjana and Peyush, 2011).

The use of fish hematological assessment is considered as a valuable tool to determine the effects of environmental pollution (Castro et al., 2020). However, the hematological characteristics of various fish species are not the same, depending on the region, habitat conditions, physiological state and diet.

The purpose of this study is to describe the comparison of the hematological parameters of red drum, Sciaenops ocellatus (Linnaeus, 1766) (Perciformes: Sciaenidae), cultured in natural water in areas with high pollution risk: the area near the river mouth with the waste-water generated from daily-life activities, estuarine areas near factories, industrial parks (in Ha Tinh province, Vietnam) and nearshore areas - where many tourism and wharves take place activities (Nha Trang city, Khanh Hoa, Vietnam).

\section{Materials and Methods}

\subsection{Location and sampling blood fish and water samples}

Red drum Sciaenops ocellatus is today one of popular species cultured in cages in the coastal areas of Vietnam and is selected as a subject for research. Sciaenops ocellatus are collected from three different culturing locations of Ho Do commune - Loc Ha district, L1 (18 ${ }^{\circ} 23^{\prime} 47.06^{\prime \prime N}$, $105^{\circ} 53^{\prime} 9.41$ ”E), Ky Ninh commune - Ky Anh town, L2 $\left(18^{\circ} 6^{\prime} 31.70 " \mathrm{~N}, 106^{\circ} 21^{\prime} 15.44^{\prime \prime} \mathrm{E}\right)$ - Ha Tinh province and the lagoon in Hon Mieu located in Nha Trang bay - Khanh Hoa province, L3 (12 $\left.11^{\prime} 4.49^{\prime \prime} \mathrm{N}, 109^{\circ} 13^{\prime} 17.40 ” \mathrm{E}\right)$.

Ho Do commune is located about $6 \mathrm{~km}$ from center of Ha Tinh province, which is the intersection of Nghen river and Ho Do river, then flow into Ha Vang river and flow to East Sea. The location of Ky Ninh commune, Ky Anh district, Ha Tinh province is very close to Vung Ang Bay, next to Son Duong-Vung Ang Port and Vung Ang economic zone, in which activities of metallurgical industry, seaport exploitation, steel industry, thermoelectric and petrochemical refinery center take place. The cage in Hon Mieu, Nha Trang Bay, Khanh Hoa is located near the intersection between Cua Be River and the East Sea and where tourism industry is well developed.

Fish collected in cages have average weight of $1150 \pm 250 \mathrm{~g}$, total length of $38.0 \pm 7.5 \mathrm{~cm}$. Each group consists of 4-5 males and 1-2 females. The sampling period took place in August-September 2019. A total of 18 Sciaenops ocellatus was studied and analyzed. In terms of appearance, all fish were healthy, not scratched, with uniform fines.

The sample of surface water was collected and preserved using method of SMEWW 3125B: 2017 (APHA, 2017) to determine the content of heavy metals ( $\mathrm{Cr}, \mathrm{Mg}$, Fe, $\mathrm{Ni}, \mathrm{Cu}$, $\mathrm{Zn}, \mathrm{As}, \mathrm{Cd}, \mathrm{Hg}, \mathrm{Pb}$ ) by Inductively coupled plasma mass spectrometry (ICP-MS).

\subsection{Erythrocyte morphology and hematological parameters}

Six samples of venous blood were collected from the tail vein, irrespective of male or female at each site. Heparin was used as an anticoagulant with a concentration of 15$20 \mu \mathrm{l}$ for every $1 \mathrm{ml}$ of fish blood. The fish blood collection tube was kept cool at $8-10^{\circ} \mathrm{C}$ for about 2 hours to transport to the laboratory (Polyclinic Hong Duc, Ha Tinh, Vietnam).

A part of blood is used for hematological indicators analysis: Hb indicator - Hematology analyzer Prokan-PE 6800 (Procan - China); biochemical indicators: Urea, Creatin, Glucose, GOP, GPT - Semi-automatic clinical chemistry analyzer 3000 EVOLUTION (Biochemical - Italia); Albumin, Globulin, Total Protein, Iron (Fe) - Auto Biochemistry analyzer AU480 Beckman Coulter (Beckman Coulter, USA).

Another amount of blood was diluted as much as 250 times with Ringer solution of Hoar and Hickman (1975) (modification of a standard Ringer's solution for marine teleost (Hoar and Hickman, 1975) consisting of $7.8 \mathrm{~g} \mathrm{NaCl}$, $0.18 \mathrm{~g} \mathrm{KCl}, 0.166 \mathrm{~g} \mathrm{CaCl}_{2}, 0.095 \mathrm{~g} \mathrm{MgSO}_{4}, 0.084 \mathrm{~g} \mathrm{NaHCO}_{3}, 0.06 \mathrm{~g}$ $\mathrm{NaH} 2 \mathrm{PO} 4$ in 1 liter water), using Neubauer hemocytometer, AmScope 40X-1000X microscope to take photos and count the number of erythrocytes with magnification of $40 \times$.

Another portion of the blood is used to prepare smears (whole blood). At the same time, another part of the blood was centrifuged at a rate of $2000 \times \mathrm{g}$ for 10 minutes and separated the leukocyte-rich blood. To make a specimen on a sterile slide by this portion of the blood (leukocyte-rich blood). Methanol was use to fix the specimen (3 minutes). To dye with Romanowsky-Giemsa $10 \%$ for 20 minutes and the smears were rinsed with buffer solution 2 times for 1 minute. Olympus CX43 microscope was used to take photos and Adobe Photoshop CS6 program to analyse the received image. Classification and counting method of cell types follows Bielek (1980, 1981), Ivanova (1983), Ivanov (2003), and Campbell (2015). Cell measurement was performed using ImageJ software (v.1.52r).

Software SPSS Statistics v.20 (IBM) was used for calculation mean, standard devitation and for all statistical analyzes. For values with standard distribution, we performed analysis using one-way ANOVA. For values without standard distribution, we used the Mann-Whitney U-test to assess whether the difference is statistically significant (with $\mathrm{p} \leq 0.05$ ).

\section{Results}

The temperature and salinity of surface water, as well as concentration of heavy metals ( $\mathrm{Cr}, \mathrm{Mn}, \mathrm{Fe}, \mathrm{Ni}, \mathrm{Zn}, \mathrm{Cd}$, $\mathrm{As}, \mathrm{Cu}, \mathrm{Pb}$ ) at research locations are given in Table 1 . The rate of morphological disorders of erythrocytes in red drum is shown in Table 2. Erythrocyte morphology size of red drum in the research locations included cell length, 
cell width, nucleus length, nucleus width, cell area and nucleus area. The ratio of nucleus area to cell area is given in Table 3. The number of erythrocytes, the percentage of leukocytes and thrombocytes compared with erythrocytes, hemoglobin, biochemical parameters such as glucose, SGPT (serum glutamic-pyruvic transaminase), SGOT (serum glutamic oxaloacetic transaminase), urea, creatine, plasma iron, albumin and total plasma protein are shown in Table 4. Microscope image of blood sample of a red drum in the locations are shown in Figure 1.

Table 1. Water parameters at the research locations.

\begin{tabular}{|c|c|c|c|c|c|c|c|}
\hline \multirow{2}{*}{ No. } & \multirow{2}{*}{ Parameters } & \multirow{2}{*}{ Unit } & \multicolumn{3}{|c|}{ Locations } & \multirow{2}{*}{ QCVN } & \multirow{2}{*}{$\mathrm{MPC}^{\mathrm{A}}$} \\
\hline & & & L1 & L2 & L3 & & \\
\hline 1 & Temperature & ${ }^{\circ} \mathrm{C}$ & 27 & 26 & 27 & - & - \\
\hline 2 & Salinity & $\%$ & 24 & 30 & 35 & - & - \\
\hline 3 & $\mathrm{Cr}$ & $\mu \mathrm{g} / \mathrm{l}$ & 0.76 & 0.43 & 0.92 & 100 & - \\
\hline 4 & $\mathrm{Mn}$ & $\mu \mathrm{g} / \mathrm{l}$ & 1.56 & 0.35 & 128.07 & 500 & - \\
\hline 5 & $\mathrm{Fe}$ & $\mu \mathrm{g} / \mathrm{l}$ & 54.78 & 81.95 & 176.23 & 500 & $\left(\mathrm{Fe}^{2+/ 3+}\right):<100-200^{*}$ \\
\hline 6 & $\mathrm{Ni}$ & $\mu \mathrm{g} / \mathrm{l}$ & 0.42 & 0.28 & - & - & $30-75^{* *}$ \\
\hline 7 & $\mathrm{Cu}$ & $\mu \mathrm{g} / \mathrm{l}$ & 0.74 & 0.44 & 1.18 & 200 & $1-10^{*}$ \\
\hline 8 & $\mathrm{Zn}$ & $\mu \mathrm{g} / \mathrm{l}$ & 4.01 & 2.61 & 7.24 & 500 & $100-1000^{* *}$ \\
\hline 9 & As & $\mu \mathrm{g} / \mathrm{l}$ & 1.39 & 1.37 & 2.34 & 20 & $3000-30000^{* *}$ \\
\hline 10 & $\mathrm{Cd}$ & $\mu \mathrm{g} / \mathrm{l}$ & 0.04 & 0.04 & 0.14 & 5 & $\begin{array}{c}0.2-1^{*} \\
2000-20000^{*}\end{array}$ \\
\hline 11 & $\mathrm{Cu}$ & $\mu \mathrm{g} / \mathrm{l}$ & ND & ND & 0.10 & 1 & $\begin{array}{l}0.3-2^{*} \\
200-4000^{* *}\end{array}$ \\
\hline 12 & $\mathrm{~Pb}$ & $\mu \mathrm{g} / \mathrm{l}$ & 2.03 & 1.36 & 1.87 & 50 & $\begin{array}{c}4-70^{*} \\
1000-100000^{* *}\end{array}$ \\
\hline
\end{tabular}

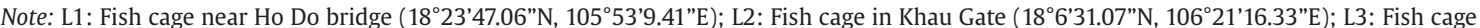
in Nha Trang Bay $\left(12^{\circ} 11^{\prime} 4.49^{\prime \prime} \mathrm{N}, 109^{\circ} 13^{\prime} 17.40^{\prime \prime}\right.$ ); ND: Not detected; QCVN: National technical regulation on marine water quality (Ministry of Natural Resources and Environment - Vietnam, VEA, 2015); MPC: maximum permissible concentration; A: Svobodova et al. (1993); *: Acceptable limitations in aquaculture, ${ }^{* *}$ : Lethal concentrations for fish, vary depending on other factors such as: inorganic and organic compounds, soft water, calcium-rich water etc.

Table 2. The rate of erythrocyte morphological disorders of red drum.

\begin{tabular}{ccccc}
\hline \multirow{2}{*}{ Location } & \multicolumn{4}{c}{ Types of RBC morphological disorders } \\
\cline { 2 - 5 } & Cellular deformation & Membrane wrinkling & Nuclear-matter distribution & Nuclear deformation \\
\hline \multirow{2}{*}{ L1 } & $1-2 \%$ & $0-3 \%$ & $63-83 \%$ & $72-87 \%$ \\
L2 & $0-1 \%$ & $1-5 \%$ & $72-82 \%$ & $65-78 \%$ \\
L3 & $0-1 \%$ & $0-2 \%$ & $0-1 \%$ & $8-25 \%$ \\
\hline
\end{tabular}

Table 3. Erythrocyte morphological parameters of red drum in locations.

\begin{tabular}{ccccc}
\hline \multirow{2}{*}{ Index } & Unit & \multicolumn{3}{c}{ Location } \\
\cline { 3 - 5 } & & L1 & L2 & L3 \\
\hline $\mathrm{CL}$ & $(\mu \mathrm{m})$ & $9.56 \pm 0.66 \mathrm{ab}$ & $10.28 \pm 0.72 \mathrm{a}$ & $10.47 \pm 0.74 \mathrm{~b}$ \\
$\mathrm{CW}$ & $(\mu \mathrm{m})$ & $8.23 \pm 0.62 \mathrm{ab}$ & $7.78 \pm 0.73 \mathrm{a}$ & $7.94 \pm 0.51 \mathrm{~b}$ \\
$\mathrm{NL}$ & $(\mu \mathrm{m})$ & $3.68 \pm 0.47 \mathrm{ab}$ & $3.18 \pm 0.30 \mathrm{a}$ & $3.20 \pm 0.21 \mathrm{~b}$ \\
$\mathrm{NW}$ & $(\mu \mathrm{m})$ & $2.60 \pm 0.41 \mathrm{a}$ & $2.37 \pm 0.31 \mathrm{ab}$ & $2.61 \pm 0.24 \mathrm{~b}$ \\
$\mathrm{Sc}$ & $\left(\mu \mathrm{m}^{2}\right)$ & $60.49 \pm 5.91 \mathrm{ab}$ & $65.85 \pm 6.30 \mathrm{a}$ & $67.24 \pm 6.50 \mathrm{~b}$ \\
$\mathrm{Sn}$ & $\left(\mu \mathrm{m}^{2}\right)$ & $9.67 \pm 1.67 \mathrm{a}$ & $7.51 \pm 0.97 \mathrm{a}$ & $6.81 \pm 0.44 \mathrm{a}$ \\
$\mathrm{Sn} / \mathrm{Sc}$ & $\%$ & $15.98 \%$ & $11.4 \%$ & $10.12 \%$ \\
\hline
\end{tabular}

Note: L1: $18^{\circ} 23^{\prime} 47.06^{\prime \prime} \mathrm{N}, 105^{\circ} 53^{\prime} 9.41^{\prime \prime E}$; L2: 186'31.07"N, 106²1'16.33”E; L3: $12^{\circ} 11^{\prime} 4.49^{\prime \prime} \mathrm{N}, 109^{\circ} 13^{\prime} 17.40^{\prime \prime} \mathrm{E}$; CL: Cell lenght; CW: Cell width; NL: Nucleus length; NW: Nucleus width; Sc: Cell area; Sn: Nucleus area; The same letter represents a statistically significant difference $(p \leq 0,05)$. 


\section{Discussion}

The research results showed that, at all research locations, the values of heavy metal were completely within the permissible limits, even much lower than Vietnam's national standards for seawater (VEA, 2015). After the disaster in 2016, caused by the Formosa plant to Ha Tinh and some central provinces of Vietnam, the sea level near Vung Ang industrial park is independently evaluated and monitored by research agencies on a regular basis (Nguyen Viet et al., 2018; Nguyen Thi et al., 2017; Pham Thi et al., 2018). The quality of seawater at locations L1 and L2 also showed that the seawater sources near river mouths and estuaries are suitable for aquaculture.

As for the location L3, despite the fact that heavy metal parameters were within safe limits for aquaculture, it was observed that the amount of Fe $\left(176.23 \mu \mathrm{g} . \mathrm{L}^{-1}\right)$ and $\mathrm{Mn}\left(128.07 \mu \mathrm{g}\right.$. $\left.\mathrm{L}^{-1}\right)$ is fairly high. According to the recommendations of FAO (Svobodova et al., 1993), water used for carp species rearing, the acceptable concentration of insoluble iron forms shall not exceed $200 \mu \mathrm{g} / \mathrm{l}$, while for salmon species - it shall be less than $100 \mu \mathrm{g} / \mathrm{l}$. Our study showed that the value of Fe in seawater used for fish farming in Nha Trang Bay is close to the recommended threshold for some fish species.

There are many studies on the influence of heavy metals on erythrocyte morphology and hematological parameters of both marine and freshwater fish species (Witeska, 1998; Buthelezi et al., 2000; Vinodhini and Narayanan, 2009; Ranjana and Peyush, 2011; Jyoti and Seema, 2014; Vesela et al., 2014; Javed and Usmani, 2014). These studies evaluated the effect of heavy metal element or a small group of elements on fish hematological parameters. In the present study, morphological and biochemical parameters of blood were studied in the natural water bodies, subjected to changes in flow, circulation of waste water sources, changes in temperature, salinity, $\mathrm{pH}$, and other factors. Moreover, at the cellular level, red drum erythrocytes were affected by the presence of many different metals simultaneously.

Table 4. Hematological parameters of red drum in cages.

\begin{tabular}{ccccc}
\hline & Unit & L1 & L2 & L3 \\
\hline Erythrocytes & $10^{6} / \mathrm{mm}^{3}$ & $2.98 \pm 0.45 \mathrm{a}$ & $1.80 \pm 0.34 \mathrm{a}$ & $1.97 \pm 0.42 \mathrm{a}$ \\
Leucocytes $^{*}$ & $\%$ & $11.82 \pm 4.21 \mathrm{ab}$ & $2.04 \pm 1.94 \mathrm{a}$ & $3.74 \pm 3.56 \mathrm{~b}$ \\
Thrombocytes $^{*}$ & $\%$ & $2.81 \pm 3.04$ & $1.72 \pm 2.07$ & $1.35 \pm 1.97$ \\
$\mathrm{Hb}$ & $\mathrm{g} / \mathrm{L}$ & $125.17 \pm 8.42$ & $133.30 \pm 9.16$ & $129.18 \pm 12.21$ \\
Glucose & $\mathrm{mmol} / \mathrm{L}$ & $17.03 \pm 1.02 \mathrm{a}$ & $12.31 \pm 0.67 \mathrm{a}$ & $15.41 \pm 2.58 \mathrm{a}$ \\
SGOT & $\mathrm{u} / \mathrm{l}$ & $64.62 \pm 11.60 \mathrm{a}$ & $26.67 \pm 8.01 \mathrm{a}$ & $31.40 \pm 5.87 \mathrm{a}$ \\
SGPT & $\mathrm{u} / \mathrm{l}$ & $16.41 \pm 1.45 \mathrm{a}$ & $18.80 \pm 3.60 \mathrm{~b}$ & $3.90 \pm 1.19 \mathrm{ab}$ \\
Urea & $\mathrm{mmol} / \mathrm{l}$ & $0.66 \pm 0.51 \mathrm{ab}$ & $1.79 \pm 0.86 \mathrm{a}$ & $2.32 \pm 0.67 \mathrm{~b}$ \\
Creatinin & $\mu \mathrm{mol} / \mathrm{l}$ & $47.18 \pm 7.25$ & $50.26 \pm 8.94 \mathrm{a}$ & $40.27 \pm 7.35 \mathrm{a}$ \\
Fe & $\mathrm{mmol} / \mathrm{l}$ & $35.54 \pm 6.31$ & $36.00 \pm 4.42$ & $38.89 \pm 5.71$ \\
Albumin & $\mathrm{g} / \mathrm{l}$ & $28.05 \pm 4.57 \mathrm{a}$ & $30.05 \pm 1.80 \mathrm{~b}$ & $12.63 \pm 1.65 \mathrm{ab}$ \\
Protein & $\mathrm{g} / \mathrm{l}$ & $61.79 \pm 10.08 \mathrm{a}$ & $64.38 \pm 3.68 \mathrm{~b}$ & $46.32 \pm 4.28 \mathrm{ab}$ \\
\hline
\end{tabular}

Note: ${ }^{*}$ - percentage compared to 100 erythrocytes, SGOT - aspartate transaminase, SGPT - alanine aminotransferase.

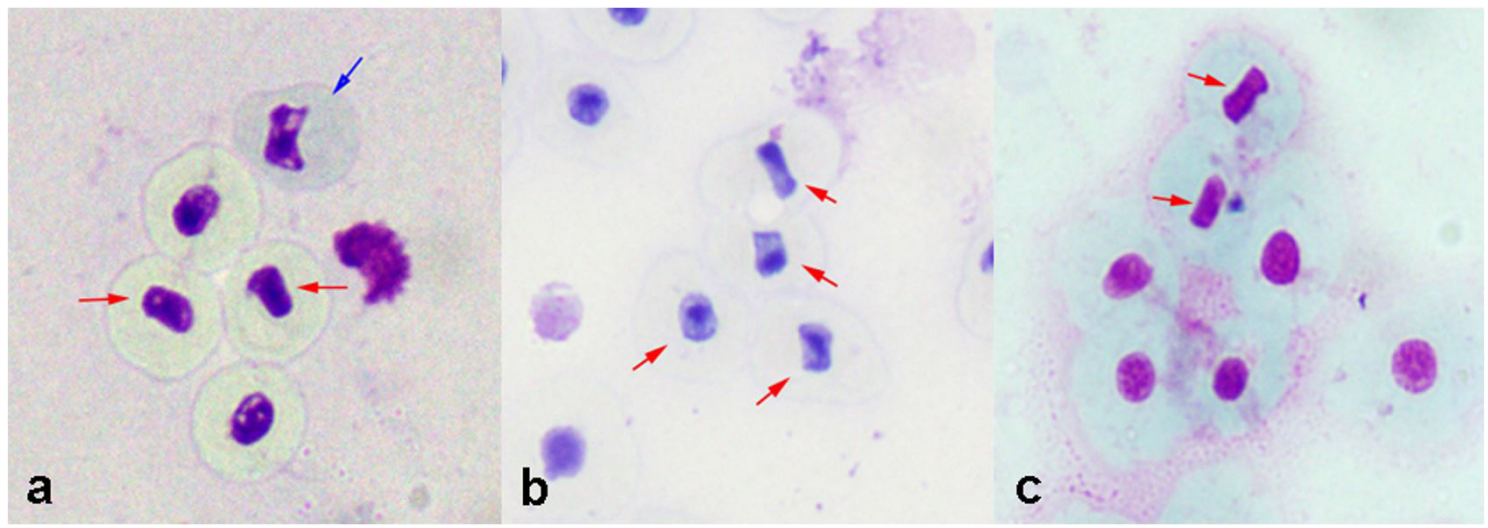

Figure 1. Erythrocytes of red drum. a - location L1, b - location L2, c - location L3. The red arrow indicates the deformed erythrocyte nuclear/uneven nuclear-matter distribution. The blue arrow indicates the slightly alkaline erythrocytes. 
On the microscope, all erythrocytes $S$. ocellatus in all three regions exhibited morphological disorders: disproportionate shape, wrinkled cell membranes, unevenly distributed nuclear matter, deformed nucleus. However, the disorder of nuclear matter distribution and nuclear deformation account for a fairly high proportion for the fish taken from L1 and L2 locations. The cultured location L3 exhibited only nuclear deformation disorders and to a lesser extent. Research by Harr et al. (2018) showed that the normal erythrocyte nucleus of $S$. ocellatus has a balanced shape, with nuclear matter evenly distributed. Erythrocyte nuclear matter disorders have been recognized in Prochilodus lineatus experiencing contamination by $\mathrm{Pb}$ (Monteiro et al., 2011), in Tinca tinca species under Cd exposure (Witeska et al., 2006) and in Cyprinus carpio experiencing $\mathrm{Cd}, \mathrm{Cu}, \mathrm{Pb}$ and $\mathrm{Zn}$ exposure (Witeska, 2004); Chromosome distribution disorders have been reported for Puntinus conchonius erythrocytes exposed to Cd (Gill and Pant, 1986). Although the values of heavy metals such as $\mathrm{Pb}, \mathrm{Cu}, \mathrm{Cd}, \mathrm{Zn}$ and other metals in water at the research locations were quite low, long-term exposure and synergistic effects have caused significant impacts on cells, resulted in high proportion of erythrocytes with morphological disorders.

Comparison between sampling areas showed that the number of erythrocytes in red drum blood in cages in L1 $(2.98 \pm 0.45)$ was higher than those in $\mathrm{L} 2(1.80 \pm 0.34)$ and L3 $(1.97 \pm 0.42)$. It should be noted that, compared with the permitted limit according to aquaculture water standards (by VEA, 2015), the heavy metal content at locations L1 and L2 were not much different, however the salt concentration in these two areas was clearly different, with L1 - $24 \%$ 。 and $\mathrm{L} 2-30 \%$. For the cage in location L3, in addition to the higher salt concentration (35\%), a higher amount of Fe and Mn than in locations L1 and L2 was observed. In addition, the fluctuation of salinity at location L3 during the day was more stable than that in L1 and L2, where it varied significantly due to the tidal impact. The observerd difference of RBC is related to the demand for energy to balance osmotic pressure with the fish's habitat (Al Hilali and Al-Khshali, 2016; Singh and Reddy, 1990; Ranjana and Peyush, 2011). Studies of red drum adapted to freshwater and seawater of showed that the number of erythrocytes in freshwater was higher than that in seawater (GullianKlanian, 2013).

The percentage of leukocytes and thrombocytes group showed great variation between culture locations. It should be noted that the round cell of immature thrombocytes could be easily confused with small lymphocytes. However, lymphocytes have slightly denser, mildly basophilic cytoplasm, and the nuclear of the lymphocyte is usually larger and less condensed (Campbell, 2015). The L1 fish group has a much larger proportion of leukocytes than the L2 and L3, which may be related to the position of the culture locations. The fish at L1 farming location is located near Ho Do Bridge, where many households discharge waste water. Therefore, this area is at higher risk of organic pollution as well as fish pathogens than locations L2 and L3 which are located at estuaries and on the coast, where there are no near direct sources of organic waste.
The serum hemoglobin and Fe contents of all fish groups, L1 (125.17 $\pm 8.42 \mathrm{~g} / \mathrm{L} ; 35.54 \pm 6.31 \mathrm{mmol} / \mathrm{L})$; L2 $(133.30 \pm 9.16 \mathrm{~g} / \mathrm{L} ; 36.00 \pm 4.42 \mathrm{mmol} / \mathrm{L}) . \mathrm{L} 3(129.18 \pm 12.21$; $38.89 \pm 5.71 \mathrm{mmol} / \mathrm{L})$ had no significant difference $(\mathrm{p} \leq 0.05)$. The Gullian-Klanian report (2013) indicated that the blood hemoglobin of S. ocellatus was higher in freshwater culture condition than in salt-water one, ranging from 7.41 to $10.49 \%$. In this research, for red drum living in brackish and salt water conditions, the salinity was different but did not affect the hemoglobin and Fe contents in blood.

The highest blood glucose content was in the L1 fish group (17.03 $\pm 1.02 \mathrm{mmol} / \mathrm{L})$, and the lowest one was in the L2 fish group ( $12.31 \pm 0.67 \mathrm{mmol} / \mathrm{L})$. The L3 group had glucose content in the middle of the abovementioned groups $(15.41 \pm 2.58 \mathrm{mmol} / \mathrm{L})$. Creatine in both L1 and L2 environments was higher than that in L3. Higher glucose and creatinine concentrations in low salinity environment could be understood as a stress reaction of fish to the environment (Wendelaar Bonga, 1997; Gullian-Klanian, 2013). The Donaldson (1981) noted that this parameter was particularly useful when determining the stress level of fish to two or more agents. Certain energy metabolites, especially glucose and lactic acid, experience significant increase in the circulatory system in response to environmental disturbances, such as salinity (Roche and Bogé, 1996).

SGOT (serum glutamic oxaloacetic transaminase) and SGPT (serum glutamic pyruvic transaminase) belong to the "family" of non-specific enzymes found in liver, heart, gill, kidney, muscle and other organs (Bell, 1968; Gaudet et al., 1975) and in the blood. They can provide valuable information about internal organ dysfunction (Casillas et al., 1983; Wells et al., 1986). Heavy metal compounds, pesticides, subletal concentration of phenol and organic pollution can cause changes in the activity of these two enzymes in fish blood (Verma et. al., 1984; Asztalos et al., 1990). SGPT is high in liver. As a result, its concentration reflects more specific liver damage than SGOT - an enzyme that can be found in many other internal organs. The content of SGOT and SGPT enzymes have significant differences between the groups ( $\mathrm{p} \leq 0.05$ ). Particularly, SGOT content of L1 was 2 times higher than that of L2 and L3, SGPT content of L1 and L2 was 4 times higher than that of L3. The higher SGPT parameters at L1 and L2 locations than L3 is highly likely related to liver damage in red drum. Moreover, SGOT parameter of L1 is higher than L2, L3, showing that in addition to possible damage to the liver, the fish group at L1 location may suffer from damage in other organs as well, or be suffering from the environmental stress. However, the lack of reference data under standard culture conditions can lead to inaccurate judgments, on whether it was the damage or stresses of fish at these farming locations.

Differences in albumin and plasma protein content in the two fish groups of $\mathrm{L} 1(28.05 \pm 4.57 \mathrm{~g} / \mathrm{l} ; 61.79 \pm 10.08 \mathrm{~g} / \mathrm{l})$ and L2 $(30.05 \pm 1.80 \mathrm{~g} / \mathrm{l} ; 64.38 \pm 3.68 \mathrm{~g} / \mathrm{l})$ were not significant statistically. On another hand, these two parameters in L3 fish group (12.63 $\pm 1.65 \mathrm{~g} / \mathrm{l} ; 46.32 \pm 4.28 \mathrm{~g} / \mathrm{l}$ ) were much lower than those in both L1 and L2. Changes in albumin and protein contents in heavy metal pollution have been reported in Channa punctatus (Javed et al., 2017), Cyprinus carpio (Gopal et al., 1997) or Oreochromis niloticus 
(Al-Asgah et al., 2015). However, the change trend was dependent on the time of exposure and differed between species. A decrease in plasma protein content was observed in C. carpio when exposed to $\mathrm{Hg}, \mathrm{Pb}, \mathrm{Cu}$ and $\mathrm{Ni}$ for 72 hours (Gopal et al., 1997) and O. niloticus when exposed to different concentrations of $\mathrm{CdCl}_{2}$ for $10,20,30$ days. With the increase of the concentration and the exposure duration protein contents decrease (Al-Asgah et al., 2015). The organism's response to the heavy metal elements showed a similar variation.

However, it did not mean that L1, L2 areas were showing less pollution levels than L3. Fish living in polluted areas showed a relatively high total protein content compared to the reference value, which was because enhanced protein synthesis may be necessary to meet the need for repair of damaged tissues and enhancement of immune response (Javed et al., 2017). Indeed, the rate of erythrocyte morphological disorders of red drum at the locations L1 and L2 were much higher than that in L3. As a result, increased protein and albumin levels may be necessary for the compensation and repair of damage to tissues as well as blood cells to help fish cope with stress.

The results of this research show that red drum in all of the three farming locations is living in the polluted environment. Although heavy metal parameters are within the permitted level (by VEA, 2015), their combined and prolonged impacts affected the fish. Blood parameters can be used to predict possible damage to tissues and organs of fish. However, more researches are needed to assess whether these red drum individuals are influenced by other factors such as toxic organic compounds, in addition to the abovementioned metal elements.

\section{Acknowledgements}

The author would like to thank Pham Huu Tinh, Head of the Department of Sea, Islands and Resources of Ha Tinh Province for facilitating and providing me with working facilities; I would like to sincerely thank to Nguyen Tai Tu and Tran Van Dat for assisting Lme in collecting of the samples. This research was conducted within the topic "Evaluation of erythrocyte morphological characteristics and hematological parameters of common fish species in the central coastal area (Ha Tinh) at risk of pollution due to discharge", approved by the Vietnam-Russia Tropical Center, funded by the Vietnamese State's funding for scientific research activities.

\section{References}

AL HILALI, H.A. and AL-KHSHALI, M.S., 2016. Effect of water salinity on some blood parameters of common carp (Cyprinus carpio). International Journal of Applied Agricultural Sciences, vol. 2, no. 1, pp. 17-20. http://dx.doi.org/10.11648/j.ijaas.20160201.13.

AL-ASGAH, N.A., ABDEL-WARITH, A.A., YOUNIS, E.M. and ALLAM, H.Y., 2015. Haematological and biochemical parameters and tissue accumulations of cadmium in Oreochromis niloticus exposed to various concentrations of cadmium chloride. Saudi Journal of Biological Sciences, vol. 22, no. 5, pp. 543-550. http:// dx.doi.org/10.1016/j.sjbs.2015.01.002. PMid:26288556.
AL-MASRI, M.S., ABA, A., KHALIL, H. and AL-HARES, Z., 2002. Sedimentation rates and pollution history of a dried lake: Al-Oteibeh Lake. The Science of the Total Environment, vol. 293, no. 1-3, pp. 177-189. http://dx.doi.org/10.1016/S00489697(02)00013-X. PMid:12109471.

AMERICAN PUBLIC HEALTH ASSOCIATION - APHA. AMERICAN WATER WORKS ASSOCIATION, WATER ENVIRONMENT FEDERATION, 2017. Standard method for the examination of water and waste water. APHA, AWWA, WEF: Washington DC, 23rd edition.

ASZTALOS, B., NEMCSOK, J., BENEDECZKY, I., GABRIEL, R., SZABO, A. and REFAIN, O.J., 1990. The effects of pesticides on some biochemical parameters of carp (Cyprinus carpio L.). Archives of Environmental Contamination and Toxicology, vol. 19, no. 2, pp. 275-282. http://dx.doi.org/10.1007/BF01056097. PMid:2322021.

BELL, G.R., 1968. Distributions of transaminases (amino-transferases) in the tissues of Pacific salmon (Oncorhynchus), with emphasis on the proterties and diagnostic use of glutamic-oxalacetic transaminase. Journal of the Fisheries Research Board of Canada, vol. 25, no. 6, pp. 1247-1268. http://dx.doi.org/10.1139/f68-108.

BIELEK, E., 1980. Electron microscopical studies of blood cells in teleosts. III. Granulocytes. Zool Jb Anat Bd, vol. 103, pp. 105-121.

BIELEK, E., 1981. Developmental stages and localization of peroxidatic activity in the leucocytes of three teleost species (Cyprinus carpio L.; Tinca tinca L.; Salmo gairdneri Richardson). Cell and Tissue Research, vol. 220, no. 1, pp. 163-180. http:// dx.doi.org/10.1007/BF00209975. PMid:7273125.

BUTHELEZI, P.P., WEPENER, V. and CYRUS, D.P., 2000. The sublethal effects of zinc at different water temperatures on selected haematological variables in Oreochromis mossambicus. African Journal of Aquatic Science, vol. 25, no. 1, pp. 146-151. http:// dx.doi.org/10.2989/160859100780177659.

CAMPBELL, T.W., 2015. Exotic animal hematology and cytology. John Wiley \& Sons, Inc. 421 p. http://dx.doi. org/10.1002/9781118993705.

CASILLAS, E., MYERS, M. and AMES, W.E., 1983. Relationship of serum chemistry values to liver and kidney histopathology in English sole (Parophrys vetulus) after acute exposure to carbon tetrachhloride.Aquatic Toxicology, vol. 3, no. 1, pp. 61-78. http:// dx.doi.org/10.1016/0166-445X(83)90007-3.

CASTRO, P.D.S., LADISLAU, D.S., RIBEIRO, M.W.S., LOPES, A.C.C., LAVANDER, H.D., BASSUL, L.A., MATTOS, D.C., LIEBL, A.R.S., ARIDE P.H.R. and OLIVEIRA A.T., 2020. Hematological parameters of three species of the peacock bass (Cichla spp.) from Balbina lake, Presidente Figueiredo, Amazonas, Brazil. Brazilian Journal of Biology, vol. 81, no. 1, pp. 62-68. https://doi.org/10.1590/15196984.219409.

DAMIEN, C., CHANTAL, V.H., PIROUZ, S., ZERIMECH, F.H., LAURENCE, J. and JEAN, M.H., 2004. Cellular impact of metal trace elements in terricolous lichen Diploschistes muscorum (Scop.) R. Sant. - identification of oxidative stress biomarkers. Water, Air, and Soil Pollution, vol. 152, no. 1-4, pp. 55-69. http://dx.doi. org/10.1023/B:WATE.0000015332.94219.ff.

DONALDSON, E.M., 1981. The pituitary-interrenal axis as an indicator of stress in fish. In: A.D. PICKERING, ed. Stress and Fish. New York: Academic Press, pp. 11-47.

FAROMBI, E.O., ADELOWO, O.A. and AJIMOKO, Y.R., 2007. Biomarkers of oxidative stress and heavy metal levels as indicators of environmental pollution in African Cat fish (Clarias gariepinus) from Nigerian Ogun River. International Journal of Environmental Research and Public Health, vol. 4, no. 2, pp. 158-165. http:// dx.doi.org/10.3390/ijerph2007040011. PMid:17617680. 
GAUDET, M., RACICOT, J.G. and LERAY, C., 1975. Enzyme activities of plasma and selected tissues in rainbow trout Salmo gairdneri Richardson. Journal of Fish Biology, vol. 7, no. 4, pp. 505-512. http://dx.doi.org/10.1111/j.1095-8649.1975.tb04625.x.

GOPAL, V., PARVATHY, S. and BALASUBRAMANIAN, P.R., 1997. Effect of heavy metals on the blood protein biochemistry of the fish Cyprinus carpio and its use as a bio-indicator of pollution stress. Environmental Monitoring and Assessment, vol. 48, no. 2, pp. 117-124. http://dx.doi.org/10.1023/A:1005767517819.

GULLIAN-KLANIAN, M., 2013. Physiological changes in the red drum after long-term freshwater acclimation. Journal of Aquatic Animal Health, vol. 25, no. 2, pp. 131-141. http://dx.doi.org/10 .1080/08997659.2013.788582. PMid:23697581.

GILL, T.S. and PANT, J.C., 1986. Chromatin condensation in the erythrocytes of fish following exposure to cadmium. Bulletin of Environmental Contamination and Toxicology, vol. 36, no. 2, pp. 199-203. http://dx.doi.org/10.1007/BF01623495. PMid:3947756.

HARR, K.E., DEAK, K., MURAWSKI, S.A., REAVILL, D.R. and TAKESHITA, R.A., 2018. Generation of red drum (Sciaenops ocellatus) hematology Reference Intervals with a focus on identified outliers. Veterinary Clinical Pathology, vol. 47, no. 1, pp. 1-7. http://dx.doi.org/10.1111/vcp.12569. PMid:29341194.

HOAR, W.S. and HICKMAN, C.P. 1975. A laboratory companion for general and comparative physiology. Englewood Cliffs, N.J: Prentice-Hall.

IVANOV, A.A., 2003. Physiology of fish. Moscow: Mir, 284 p.

IVANOVA, N.T., 1983. Atlas of fish blood cells. Comparative morphology and classification of fish blood cells. Moscow: Light and Food Industry, $182 \mathrm{p}$.

JAVED, M. and USMANI, N., 2014. Assessment of heavy metals (Cu, $\mathrm{Ni}, \mathrm{Fe}, \mathrm{Co}, \mathrm{Mn}, \mathrm{Cr}, \mathrm{Zn}$ ) in rivulet water, their accumulations and alterations in hematology of fish Channa punctatus. African Journal of Biotechnology, vol. 13, no. 3, pp. 492-501. http:// dx.doi.org/10.5897/AJB2013.13131.

JAVED, M., AHMAD, M.I., USMANI N. and AHMAD, M., 2017. Multiple biomarker responses (serum biochemistry, oxidative stress, genotoxicity and histopathology) in Channa punctatus exposed to heavy metal loaded waste water. Scientific Reports, vol. 7, pp. 1675. http://dx.doi.org/10.1038/s41598-017-01749-6.

JYOTI, S. and SEEMA, L., 2014. Effect of Manganese on haematological parameters of fish, Garra gotyla gotyla. Journal of Entomology and Zoology Studies, vol. 2, no. 3, pp. 77-81.

KARBASSI, A.R., BIATI, A. and MOATTA, F., 2006. Origin and chemical partioning of heavy metals in riverbed sediments. International Journal of Environmental Science and Technology, vol. 3, no. 1, pp. 35-42. http://dx.doi.org/10.1007/BF03325905.

LIVINGSTONE, D.R., 2001. Contaminant - stimulated reactive oxygen species production and oxidative damage in aquatic organisms. Marine Pollution Bulletin, vol. 42, no. 8, pp. 656666. http://dx.doi.org/10.1016/S0025-326X(01)00060-1. PMid:11525283.

MONTEIRO, V., CAVALCANTE, D.G.S.M., VILÉLA, M.B.F.A., SOFIA, S.H. and MARTINEZ, C.B.R., 2011. In vivo and in vitro exposures for the evaluation of the genotoxic effects of lead on the Neotropical freshwater fish Prochilodus lineatus. Aquatic Toxicology, vol. 104, no. 3-4, pp. 291-298. http://dx.doi.org/10.1016/j. aquatox.2011.05.002. PMid:21652016.

NGUYEN THI, M.P., NGUYEN NGOC, A. and NGO, Q.P., 2017. Using benthos to evaluate the quality of marine environment: case study from Central Vietnam after the incident caused by Formosa. Vietnam Journal of Science and Technology, vol. 55, no. 4C, pp. 155-161.
NGUYEN VIET, A., ANH, B.T.K. and NGO, H.G., 2018. Design of wetland system for wastewater quality improvement at Formosa Ha Tinh steel company. Vietnam Journal of Science and Technology, vol. 56, no. 2C, pp. 165-171.

PHAM THI, M.H., DUONG, T.N., TRAN, D.L., NGUYEN VAN, Q., DANG, T.B. and PHAM HUNG, V., 2018. The status and distribution of PCBs along the coast of Vietnam. Environmental Geochemistry and Health. http://dx.doi.org/10.1007/s10653-018-0168-y. PMid:30094588.

VIETNAM ENVIRONMENT ADMINISTRATION - VEA. MINISTRY OF NATURAL RESOURCES AND ENVIRONMENT - MONRE, 2015. QCVN 10-MT:2015/BTNMT. National Technical Regulation on Coastal Water Quality. Vietnam.

RANJANA, S. and PEYUSH, P., 2011. Effect of heavy metal on biochemical and hematological parameters in Cyprinus carpio and its use as a bioindicators of pollution stress. Journal of Ecophysiology and Occupational Health, vol. 11, pp. 21-28.

ROCHE, H. and BOGE, G., 1996. Fish blood parameters as a potential tool for identification of stress caused by environmental factors and chemical intoxication. Marine Environmental Research, vol. 41, no. 1, pp. 27-43. http://dx.doi.org/10.1016/01411136(95)00015-1.

SINGH, H.S. and REDDY, T.V., 1990. Effect of copper sulfate on hematology, blood chemistry, and hepato-somatic index of an Indian catfish, Heteropneustes fossilis (Bloch), and its recovery. Ecotoxicology and Environmental Safety, vol. 20, no. 1, pp. 30-35. http://dx.doi.org/10.1016/0147-6513(90)90043-5. PMid:2226241.

SVOBODOVA, Z., LLOYD, R., MACHOVA, J. and VYKUSOVA, B., 1993. Water quality and fish health (FIFAC Technical paper, no 54). Rome, FAO, pp. 20-27.

VERMA, S.R., CHAND, R. and TONK, I.P., 1984. Mercuric chloride stres on serum transaminase activity in Notopterus notopterus. Toxicology Letters, vol. 20, no. 1, pp. 49-52. http://dx.doi. org/10.1016/0378-4274(84)90181-4. PMid:6229904.

VESELA, Y., STELA, S., ILIANA, V., SLAVEYA, P. and ELENKA, G., 2014. Metal bioaccumulation in common carp and rudd from the Topolnitsa reservoir, Bulgaria. Arhiv za Higijenu Rada $i$ Toksikologiju, vol. 65, no. 1, pp. 57-66.

VINODHINI, R. and NARAYANAN, M., 2009. The impact of toxic heavy metals on the hematological parameters in common carp (Cyprinus carpio L.). Iranian Journal of Environmental Health Sciences E Engineering, vol. 6, no. 1, pp. 23-28.

WELLS, R.M.G., MCLNTYRE, R.H., MORGAN, A.K. and DAVIE, P.S., 1986. Physiological stres responses in big gamefish after capture: observation on plasma chemistry and blood factors. Comparative Biochemistry and Physiology, vol. 84A, no. 3, pp. 565-571. http://dx.doi.org/10.1016/0300-9629(86)90366-X. PMid:2874936.

WENDELAAR BONGA, S.E., 1997. The stress response in fish. Physiological Reviews, vol. 77, no. 3, pp. 591-625. http://dx.doi. org/10.1152/physrev.1997.77.3.591. PMid:9234959.

WITESKA, M., 1998. Changes in selected blood indices of common carp after acute exposure to cadmium. Acta Veterinaria Brno, vol. 67, no. 4, pp. 289-293. http://dx.doi.org/10.2754/ avb199867040289.

WITESKA, M., 2004. The effect of toxic chemicals on blood cell morphology in fish. Fresenius Environmental Bulletin, vol. 13, pp. 1379-1384.

WITESKA, M., JEZIERSKA, B. and WOLNICKI, J., 2006. Respiratory and hematological response of Tench, Tinca tinca (L.) to a short-term cadmium exposure. Aquaculture International, vol. 14, no. 1-2, pp. 141-152. http://dx.doi.org/10.1007/s10499-005-9020-3. 